\title{
PENERAPAN MODEL PEMBELAJARAN INKUIRI TERBIMBING (GUIDED INQUIRY) DENGAN MEDIA DIAGRAM V UNTUK MENINGKATKAN SIKAP ILMIAH DAN PRESTASI BELAJAR SISWA PADA MATERI HIDROLISIS GARAM KELAS XI MIPA 2 SMA NEGERI 1 BANYUDONO TAHUN PELAJARAN 2017/2018
}

\author{
Luthfiya Dinda ${ }^{*}$, Budi Utami, dan Sulistyo Saputro \\ Program Studi Pendidikan Kimia, FKIP, Universitas Sebelas Maret, Surakarta, Indonesia \\ * Keperluan korespondensi, tel/fax: +6281-567740927, email: luthfiyadinda@gmail.com
}

\begin{abstract}
ABSTRAK
Penelitian ini bertujuan untuk meningkatkan sikap ilmiah dan prestasi belajar siswa kelas XI MIPA 2 SMA Negeri 1 Banyudono tahun pelajaran 2017/2018. Jenis penelitian ini adalah Penelitian Tindakan Kelas (PTK) yang dilaksanakan dalam dua siklus. Setiap siklus terdiri dari empat tahap yaitu perencanaan tindakan, pelaksanaan tindakan, observasi, dan refleksi. Subjek penelitian adalah siswa kelas XI MIPA 2 yang berjumlah 35 siswa. Teknik pengumpulan data melalui wawancara, observasi, angket, tes, dan dokumentasi. Teknik analisis data menggunakan analisis deskriptif-kualitatif. Hasil penelitian ini menunjukkan bahwa persentase ketercapaian sikap ilmiah siswa pada pra-siklus adalah $31,14 \%$, pada siklis I meningkat menjadi $82,86 \%$. Persentase ketuntasan siswa untuk aspek pengetaahuan pada siklus I adalah $40 \%$, kemudian meningkat menjadi $71 \%$ pada siklus II. Ketuntasan aspek sikap pada siklus I sebesar $91,43 \%$. Ketuntasan aspek keterampilan pada siklus I sebesar $85,71 \%$.
\end{abstract}

Kata Kunci: inkuiri terbimbing, diagram V, hidrolisis garam, prestasi belajar, sikap ilmiah

\section{PENDAHULUAN}

Pendidikan merupakan kunci utama bagi suatu bangsa yang ingin maju di era persaingan global yang semakin ketat. Dengan pendidikan yang baik maka akan menghasilkan sumber daya manusia (SDM) yang berkualitas guna mendukung pembangunan negara dalam berbagai sektor. Salah satu mata pelajaran wajib untuk semua siswa jurusan IImu Pengetahuan Alam adalah kimia. Ilmu kimia adalah cabang ilmu pengetahuan yang mempelajari materi yang bersifat abstrak yang berkaitan dengan kajian-kajian tentang struktur maupun komponen materi, sifat/karakter materi, perubahan yang terjadi didalamnya, serta hukum-hukum yang berkenaan dengan perubahan-perubahan tersebut [1]. IImu kimia erat hubungannya dengan kehidupan sehari-hari, akan tetapi masih banyak siswa yang merasa kesulitan dengan pelajaran kimia dikare- nakan sifatnya yang bersifat abstrak tersebut.

SMA Negeri 1 Banyudono adalah sekolah yang sudah menerapkan kurikulum 2013. Kriteria Ketuntasan Minimal (KKM) untuk mata pelajaran kimia yang ditetapkan oleh SMA Negeri 1 Banyudono ini adalah 75. Artinya siswa dengan nilai di bawah KKM atau di bawah 75 dinyatakan tidak tuntas dan perlu mengikuti remidial. Hasil observasi menunjukkan bahwa partisipasi siswa saat proses belajar mengajar masih sangat kurang. Guru lebih mendominasi saat proses pembelajaran, dimana model yang digunakan masih berpusat pada guru (Teacher Centered Learning). Selama proses belajar mengajar berlangsung, guru lebih sering melakukan ceramah dengan mentransfer konsepkonsep secara langsung kepada siswa. Siswa secara pasif menerima pengetahuan yang disampaikan oleh guru atau 
yang terdapat dalam buku pelajaran. Hasil kajian dokumen menunjukkan bahwa prestasi belajar kimia siswa masih rendah. Masih rendahnya hasil belajar siswa dalam pelajaran kimia dapat dilihat dari nilai rata-rata UAS murni mata pelajaran Kimia semester ganjil, Tahun Ajaran 2017/2018 yang disajikan dalam Tabel 1.

Tabel 1. Nilai Rata-rata UAS Kimia Semester Ganjil Tahun pelajaran $2017 / 2018$

\begin{tabular}{ccc}
\hline No & Kelas & $\begin{array}{c}\text { Nilai Rata-rata } \\
\text { UAS Kimia }\end{array}$ \\
\hline 1. & XI IPA 1 & 33,38 \\
2. & XI IPA 2 & 39,57 \\
3. & XI IPA 3 & 39,77 \\
\hline
\end{tabular}

Salah satu materi kimia yang cukup sulit adalah materi hidrolisis garam. Materi hidrolisis garam menuntut siswa menguasai materi secara konseptual maupun seimbolik, siswa harus mampu menguasai secara konseptual hidrolisis garam dalam kehidupan sehari-hari sampai dengan pengionan garam hidrolisis dalam air. Dalam ranah simbolik siswa dapat menentukan mulai dari tetapan kesetimbangan hidrolisis, $\mathrm{pH}$, rumus serta reaksi yang terjadi dalam pada garam yang mengalami hidrolisis. Selain itu untuk memahami materi ini siswa harus paham materi lain atau subkonsep yang terkait dengan materi ini seperti larutan asam-basa, dan $\mathrm{pH}$ larutan. Kesulitan siswa SMA Negeri 1 Banyudono dalam materi hidrolisis garam dapat ditunjukkan dengan nilai ketuntasan pada materi tersebut yang tergolong rendah yang ditunjukan dalam Tabel 2 .

Tabel 2. Data Ketuntasan Siswa Kelas XI MIPA Materi Hidrolisis Garam Tahun Pelajaran 2016/2017

\begin{tabular}{cccc}
\hline No & Kelas & $\begin{array}{c}\text { Nilai } \\
\text { rata- } \\
\text { rata }\end{array}$ & $\begin{array}{c}\text { Ketuntasan } \\
(\%)\end{array}$ \\
\hline 1. & XI MIPA 1 & 39,69 & 9,09 \\
2. & XI MIPA 2 & 29,16 & 6,45 \\
\hline
\end{tabular}

Hasil pengamatan proses pembelajaran kimia di kelas dapat diketahui bahwa siswa kelas XI MIPA 2 tergolong kurang aktif saat pembelajaran dibandingkan kelas yang lain. Siswa kelas XI MIA 2 ini terdiri dari 35 orang dimana beberapa siswa sering tidak fokus atau tidak memperhatikan penjelasan dari guru. Berdasarkan wawan-cara dengan guru kimia mengemukakan bahwa sikap ilmiah siswa dalam pembelajaran kimia cenderung kurang terutama pada kelas XI MIPA 2. Hal tersebut semakin diperkuat dengan hasil penilaian sikap ilmiah prasiklus yang dapat dilihat pada Tabel 3 .

Tabel 3. Hasil Penilaian Sikap Ilmiah Prasiklus

\begin{tabular}{clcc}
\hline Aspek & Kategori & $\begin{array}{c}\text { Jumlah } \\
\text { Siswa }\end{array}$ & $\begin{array}{c}\text { Presentase } \\
(\%)\end{array}$ \\
\hline XI & Tuntas & 19 & 55,88 \\
MIPA 1 & Tidak & 15 & 44,12 \\
\hline Tuntas & & 37,14 \\
XI & Tuntas & 13 & 62,86 \\
\hline
\end{tabular}

Fakta lain yang ditemukan saat observasi ialah, siswa kelas XI MIPA 2 cenderung kurang berani mengungkapkan pendapat ketika berdiskusi. Ketika guru mengajukan pertanyaan atau memberi kesempatan siswa untuk menjawab pertanyaan, siswa cenderung pasif dan takut. Terlihat juga bahwa terdapat beberapa siswa yang kurang tertarik mengikuti pembelajaran kimia, beberapa ada yang berbicara sendiri dengan teman sebangkunya dan ada juga yang bercanda dengan teman lainnya. Hal ini, membuktikan bahwa sikap rasa ingin tahu, kritis, tekun, percaya diri yang merupakan bagian dari karakteristik sikap ilmiah pada siswa XI MIPA 2 dinilai belum cukup baik.

Berdasarkan uraian permasalahan yang ditemui dalam proses pembelajaran kimia di SMA Negeri 1 Banyudono, solusi yang dapat diambil adalah dengan mengganti model pembelajaran konvensional dengan model pembelajaran Inkuiri Terbimbing (Guided Inquiry) dengan media Diagram V. Model pembelajaran inkuiri menekankan pada pengalaman belajar langsung melalui penggunaan dan pengembangan keterampilan proses dan sikap ilmiah. Model pembelajaran inkuiri terbimbing merupa- 
kan salah satu model pem-belajaran yang berorientasi pada teori konstruktivistik yang mendorong siswa untuk dapat mencari makna dan membangun pengetahuannya secara individu berdasarkan pengalaman di lingkungannya [2]. Model pembelajaran inkuiri terbimbing menuntut siswa untuk mendapatkan pengetahuan malalui tahap merumuskan masalah, mengusul-kan hipotesis, mengumpulkan data, memverifikasi hasil, dan generalisasi dengan menarik kesimpulan [3]. Dalam penerapan model inkuiri terbimbing ini guru dituntut untuk bagaimana mengajar secara konstruktif, untuk memperkuat kompetensi siswa dan meningkatkan keterlibatan siswa. Siswa mengambil tanggung jawab utama dalam kegiatan pembelajaran melalui partisipasi praktis dimana guru hanya memiliki andil untuk membimbing dan mendukung siswa [4]. Sedangkan diagram $\mathrm{V}$ merupakan media tambahan yang diharapkan dapat membantu siswa menyusun kerangka berpikir dalam menemukan konsep atau memecahkan suatu permasalahan. Melalui penggunaan diagram Vee, para siswa dapat melihat hubungan antara apa yang mereka telah ketahui den pengamatan baru yang akan mereka hasilkan dan mencoba memahaminya [5]. Gambaran lengkap diagram vee beserta unsurunsurnya dapat dilihat pada Gambar 1 .

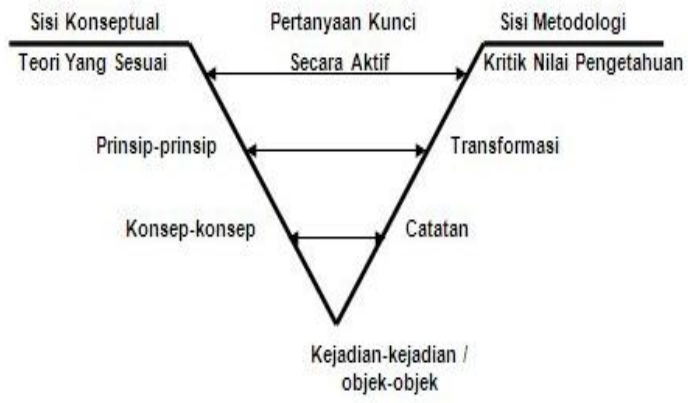

Gambar 1. Diagram Vee (Novak \& Gowin, 1985: 56)

Tujuan model pembelajaran inkuiri adalah meningkatkan kemampuan berpikir, bekerja dan bersikap ilmiah serta berkomunikasi sebagai salah satu aspek penting kecakapan hidup [6]. Model pembelajaran inkuiri terbimbing (Guided Inquiry) yang diimplementasikan di kelas dapat membantu siswa meningkatkan pembelajaran yang ber-makna dan juga meningkatkan prestasi belajar siswa pada materi hidrolisis garam. Vlassi dan Karaliota [7] menyatakan bahwa model inkuiri terbimbing memberikan hasil belajar yang lebih tinggi daripada model pembelajaran konvensional. Selain itu, penelitian yang dilakukan oleh Dewi [8] menyebutkan bahwa sikap ilmiah siswa yang mengikuti pembelajaran dengan metode inkuiri terbimbing lebih baik daripada siswa yang mengikuti pembelajaran dengan menggnakan model pembelajaran konvensional

Berdasarkan dari uraian diatas, maka peneliti bermaksud mengadakan penelitian yang bertujuan untuk meningkatkan sikap ilmiah dan prestasi belajar siswa kelas XI MIPA 2 SMA Negeri 1 Banyudono dengan judul "Penerapan Model Pembelajaran Inkuiri Terbimbing (Guided Inquiry) dengan Media Diagram V Untuk Meningkatkan Sikap Ilmiah dan Prestasi Belajar Siswa Pada Materi Hidrolisis Garam Kelas XI MIPA 2 SMA Negeri 1 Banyudono Tahun Pelajaran 2017/2018".

\section{METODE PENELITIAN}

Penelitian ini dilakukan di SMA Negeri 1 Banyudono Kabupaten Boyolali pada kelas XI MIA 2 tahun pelajaran 2017/2018. Penelitian ini merupakan Penelitian Tindakan Kelas (PTK) yang dilakukan dalam dua siklus. Tiap siklus terdiri dari empat tahap yaitu perencanaan tindakan, pelaksanaan tindakan, observasi, dan refleksi [9].

Teknik pengumpulan data dilakukan dengan observasi, angket, wawancara, dan kajian dokumen. Instrument yang digunakan dalam penelitian ini adalah RPP, Silabus, diagram V. Instrumen penilaian yang digunakan terdiri dari instrument penilaian sikap ilmiah, pengetahuan, sikap, danketerampilan. Teknik analisis data menggunakan analisis deskriptif kualitatif yang mengacu pada model analisis Miles dan Huberman yang dilakukan dalam tiga komponen yaitu reduksi data, penyajian data dan penarikan kesimpulan dan verifikasi [10]. 


\section{HASIL DAN PEMBAHASAN}

Berdasarkan observasi dikelas dapat diketahui bahwa bahwa kegiatan belajar mengajar masih berpusat pada guru (Teacher Centered Learning) yaitu dengan model ceramah. Menurut guru kimia kelas XI MIPA di SMA Negeri Banyudono, permasalahan utama yang muncul pada siswa bukan hanya prestasi belajar yang rendah saja, sikap yang ditunjukkan siswa selama mengikuti pembelajaran juga belum bisa dinyatakan baik. Siswa kurang memperhatikan saat kegiatan belajar mengajar berlangsung, dan keaktifan siswa dikelas masih rendah. Pembelajan kimia di SMA Negeri 1 Banyudono jarang mengguna-kan praktikum karena keterbatasan alat dan bahan, serta fungsi laboratorium yang belum bisa digunakan secara optimal. Hasil penilaian sikap ilmiah prasiklus yang dilakukan pada kelas XI MIPA 1 menunjukkan siswa yang tuntas sebanyak 19 siswa atau $55,88 \%$ dan untuk kelas XI MIPA 2 siswa yang tuntas sebanyak 13 siswa atau 37,14\%. Hasil tersebut menjunjukkan bahwa siswa kelas XI MIPA 2 memiliki sikap ilmiah yang lebih rendah dari kelas XI MIPA 1, dan selanjutnya penelitian ini dilakukan pada kelas XI MIPA 2.

\section{Siklus I}

Pada tahap perencanaan dilakukan penyusunan instrumen penelitian dan instrument penilaian. Silabus yang digunakan adalah silabus resmi kurikulum 2013 pelajaran kimia pada materi hidrolisis garam. Berdasarkan silabus tersebut selanjutnya peneliti menyusun rencana pelaksanaan pembelajaran (RPP).

Instrumen penilaian aspek pengetahuan berupa soal tes pilihan ganda yang terdiri dari 20 soal pilihan ganda. Instrumen ini telah diujicobakan kemudian dianalisis untuk mengetahui validitas isi, reliabilitas, daya pembeda, dan tingkat kesukaran. Instrumen penilaian aspek sikap yang berupa angket juga diujicobakan dan dianalisis untuk mengukur validitas dan reliabilitasnya. Instrumen penilaian sikap ilmiah yang berupa anget juga diujicobakan terlebih dahulu. Untuk penilaian aspek sikap dan sikap ilmiah selain menggunakan angket juga mengguna-kan lembar observasi dan wawancara yang sudah di ukur validitasnya. Instrumen penilaian aspek keterampilan menggunakan lembar observasi saat siswa melakukan praktikum sederhana. Pelaksanaan pembelajaran pada siklus I dilakukan 3 kali pertemuan untuk materi, dan 1 kali pertemuan untuk evaluasi dimana masing-masing pertemuan terdiri dari 2 JP.

Kegiatan pembelajaran dengan model pembelajaran inkuiri terbimbing diawali dengan guru mengkondisikan siswa dan mengecek kehadiran siswa. Selanjutnya guru memulai pelajaran dengan menyampaikan tujuan dan kegiatan yang akan dilakukan. Guru kemudian menerangkan secara singkat inti dari materi yang akan dibahas. Siswa dipersilahkan bergabung dengan kelompok yang telah ditentukan sebelumya dan memulai kegiatan pembelajaran bersama kelompoknya masing-masing.

Pada pertemuan pertama, kegiatan pembelajaran dilakukan dengan praktikum sederhana mengenai jenis-jenis garam yang terhidrolisis. Guru mengarahkan siswa untuk merumuskan hipotesis dan merancang percobaan untuk membuktikan hipotesis yang dibuat dengan pedoman buku paket siswa. Selanjutnya, siswa memulai kegiatan praktikum dan menganalisis data yang diperoleh kemudan menulis-kan hasilnya dalam diagram V. Selama kegiatan berlangsung siswa terlihat antusias dan aktif walaupun pada awal kegiatan masih terlihat bingung. Pada saat diskusi dengan kelompok siswa keaktifan siswa terkadang membuat kelas gaduh dan kurang tertib. Tahap terakhir yaitu siswa mengkomunikasikan kesimpulan hasil diskus kelompok dan ditutup dengan pembenaran maupun penguatan dari guru.

Pada pertemuan kedua, kegiatan yang dilakukan sama dengan pada pertemuan pertama hanya praktikum yang dilakukan mengenai sifat garam yang terhidrolisis. Pada pertemuan kedua ini kegiatan pembelajaran berlangsung lebih tertib daripada pertemuan 
pertama dan antusiasme siswa masih sama besarnya.

Pada pertemuan ketiga kegiatan pembelajaran difokuskan pada latihan soal-soal penentuan $\mathrm{pH}$ larutan garam yang terhidrolisis. Guru mengulas kembali materi sebelumnya dan menerangkan materi secara singkat. Kemudian siswa bergabung kembali dengan kelompoknya untuk menyelesaikan soalsoal yang telah dipersiapkan. Diskusi berlangsung dengan tertib dan ketika diminta maju menuliskan hasil pekerjaan kelompok didepan siswa aktif tunjuk tangan.

Hasil penilaian sikap ilmiah siswa pada siklus I dapat dilihat pada Gambar 2.

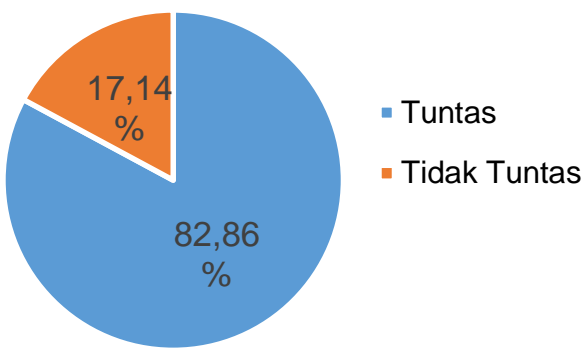

Gambar 2. Persentase Ketuntasan Sikap IImiah Siklus I

Berdasarkan Gambar 1 ketuntasan sikap ilmiah siswa kelas XI MIPA 2 adalah sebesar $82,86 \%$. Hasil ini sudah memenuhu target yang ditentukan yaitu sebesar $70 \%$ sehingga tidak perlu dilakukan penilaian kembali paad siklus II.

Hasil penilaian aspek pengetahuan pada siklus I disajikan pada Gambar 3.

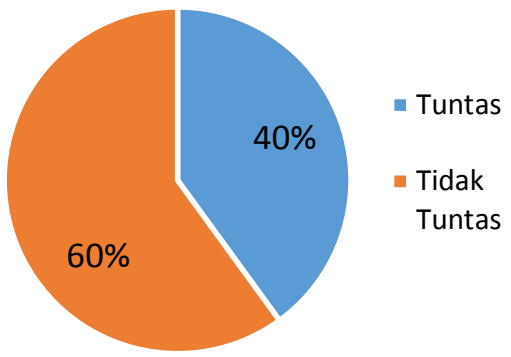

Gambar 3. Persentase Ketuntasan Aspek Pengetahuan Siklus I

Berdasarkan Gambar 2, ketunasan aspek pengetahuan siswa sebesar $40 \%$ atau masih berada dibawah target yang ditentukan yaitu sebesar $65 \%$. Hasil ketercapaian dari tiga indikator kompetensi diperoleh hasil bahwa pada indikator kompetensi pertama sudah mencapai target yaitu sebesar $70 \%$. Indikator kompetensi kedua juga sudah mencapai target dengan persentase ketercapaian sebesar $65 \%$. Akan tetapi, pada indikator kompetensi ke tiga belum mencapai target karena persentase ketercapaian yang hasilkan sebesar $47 \%$. Indikator yang belum tercapai tersebut adalah menghitung $\mathrm{pH}$ larutan garan yang terhidrolisis.

Hasil penilaian aspek sikap pada siklus I disajikan pada Gambar 4.

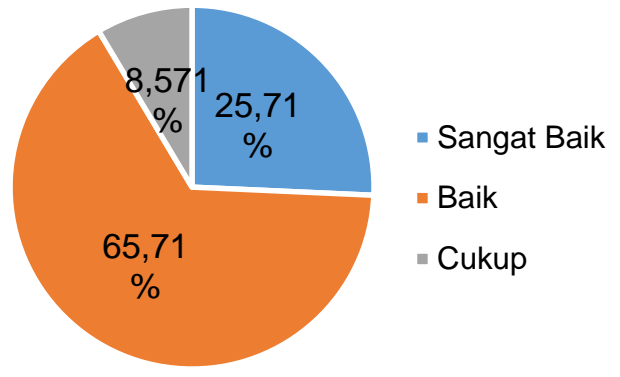

Gambar 4. Hasil Penilaian Aspek Sikap Siklus I

Persentase ketuntasan siswa dilihat dari banyaknya siswa dengan kategori sikap sangat baik dan baik yaitu sebesar 91,43\%. Target ketuntasan aspek sikap yang ditentukan adalah sebesar $70 \%$, artinya hasil yang diperoleh sudah memenuhi target dan tidak perlu dilakukan kembali pada siklus II.

Hasil penilaian aspek keterampilan siklus I dapat dilihat 5.

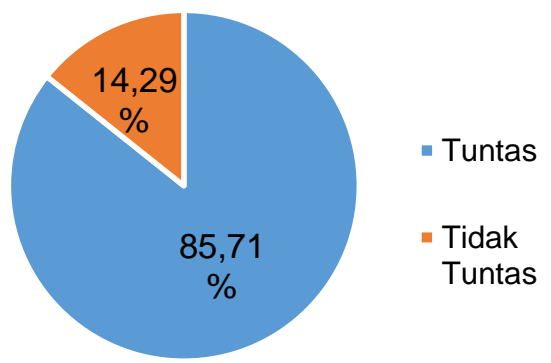

Gambar 5. Persentase Ketuntasan Aspek Keterampilan Siklus I

Berdasarkan Gambar 5, penilaian aspek keterampilan siswa menunjukkan siswa yang mencapai target ketuntasan sebanyak $85 \%$ dimana hasil tersebut 
telah melampaui target yang ditetapkan yaitu sebesar $70 \%$.

Ketercapaian masing-masing aspek pada siklus I dapat dilihat pada Tabel 4.

Tabel 4. Katercapaian Target Siklus I

\begin{tabular}{|c|c|c|c|}
\hline \multirow[b]{2}{*}{$\begin{array}{c}\text { Aspek yang } \\
\text { Dinilai }\end{array}$} & \multicolumn{2}{|c|}{$\begin{array}{l}\text { Target Akhir } \\
\text { Siklus }\end{array}$} & \multirow[b]{2}{*}{ Kriteria } \\
\hline & $\begin{array}{c}\text { Target } \\
(\%)\end{array}$ & $\begin{array}{c}\text { Keterca } \\
\text { paian } \\
(\%)\end{array}$ & \\
\hline Sikap ilmiah & 70 & 82,86 & Tercapai \\
\hline Pengetahuan & 65 & 40,00 & $\begin{array}{l}\text { Belum } \\
\text { Tercapai }\end{array}$ \\
\hline Sikap & 70 & 91,42 & Tercapai \\
\hline Keterampilan & 70 & 85,71 & Tercapai \\
\hline
\end{tabular}

Pada siklus I masih terdapat aspek yang belum mencapai target yaitu aspek pengetahuan sehingga perlu dilaksanakan siklus II. Dari tiga indikator pada aspek pengetahuan, terdapat satu indikator yang belum tuntas yaitu menghitung $\mathrm{pH}$ larutan garam yang terhidrolisis. Belum tercapainya indikator tersebut dikarenakan siswa masih belum bisa membedakan dengan jelas penggunaan masing-masing rumus untuk garam yang terbentuk dari asam kuat+basa lemah, asam lemah+basa kuat, ataupun asam lemah+basa lemah. Siswa masih terbolak-balik dalam menggunakan rumus. Selain itu, siswa masih kesulitan untuk menjawab soal pengembangan apabila yang ditanyakan adalah variabel lain yang ada dalam rumus. Kemampuan siswa untuk mengkonversi satuan dan menghubung-kan dengan rumus lain yang telah diajarkan pada materi sebelumnya juga masih sangat kurang. Terakhir faktor penting lain yang mempengaruhi tidak tercapainya indikator kompetensi ketiga adalah siswa kurang latihan mengerjakan soal-soal.

\section{Siklus II}

Kegiatan yang dilakukan pada siklus II lebih difokuskan pada penyempurnaan dan perbaikan terhadap kendala-kendala dan ketidaktercapaian aspek yang terdapat pada siklus I. Materi yang diajarkan pada siklus II adalah hidrolisis garam secara umum tetapi lebih difokuskan pada indikator pembela- jaran yang belum tuntas pada siklus I yaitu menentukan $\mathrm{pH}$ larutan garam yang terhidrolisis. Siklus II dilakukan selama 2 JP untuk penguatan materi pada indikator yang belum tuntas dan $1 \mathrm{JP}$ untuk evaluasi tes siklus II.

Kegiatan awal yang dilakukan adalah guru mengingatkan kembali materi hidrolisis garam dan mengulas kembali tentang penentuan $\mathrm{pH}$ larutan garam yang terhidrolisis. Selanjutnya siswa membentuk kelompok dan berdiskusi untuk menyelesaikan soal tentang $\mathrm{pH}$ garam yang terhidrolisis. Pada tahap ini guru lebih intens mengecek masing-masing kelompok dan memberi pengarahan. Terlihat siswa melakukan diskusi dengan aktif tetapi masih dalam keadaan yang kondusif. Siswa kemudian menuliskan dan menjelaskan jawabannya didepan kelas yang diberi tanggapa oleh kelompok siswa lain dan dari sini proses interaksi berjalan yang selanjutnya akan dibenarkan ataupun diberikan penguatan oleh guru.

Berdasarkan pengamatan pada kegiatan pembelajaran di siklus II ini terlihat sikap siswa yang lebih fokus dan teratur. Tidak banyak siswa yang membuat gaduh saat pembelajaran dan juga kontribusi tiap siswa pada kelompoknya bisa terlihat. Selama diskusi berlangsung, sisw dengan berani dan percaya diri menanyakan hal yang kurang dimengerti kepada guru. Pada tahap pembuktian banyak siswa yang dengan antusias untuk maju mengerjakan soal didepan mewakili kelompoknya.

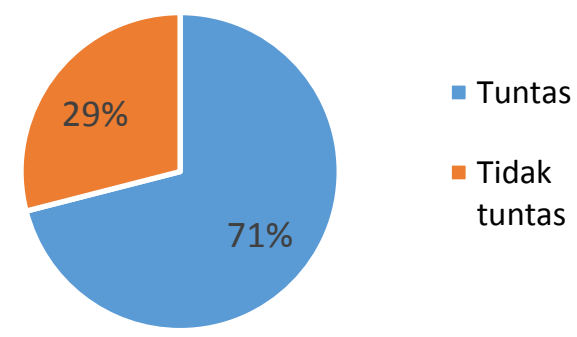

Gambar 6. Persentase Ketuntasan Aspek Pengetahuan Siklus II

Penilaian aspek pengetahuan dilakukan diakhir siklus II yang hanya dilakukan pada indikator yang belum tuntas yaitu menghitung $\mathrm{pH}$ larutan 
garam yang terhidrolisis. Tes aspek pengetahuan terdiri dari 12 soal plihan ganda dengan waktu bengerjaan selama 45 menit. Persentase ketuntasan siswa pada aspek pengetahuan siklus II dapat dilihat pada Gambar 6 .

Hasil yang ditunjukkan dari pelaksanaan siklus II sudah memenuhi indikator keberhasilan yang telah ditetapkan. Pada siklus II dilakukan perbaikan terhadap aspek pengetahuan siswa, hasilnya sebanyak 25 dari 35 siswa atau $75 \%$ siswa dinyatakan tuntas dengan target yang ditetapkan adalah sebesar $65 \%$. Dengan demikian, seluruh target telah tercapai dan tindakan dihentikan

\section{Perbandingan Antar Siklus}

Perbandingan hasil tindakan siklus I dan 2 pada aspek pengetahuan dapat dilihat pada Gambar 7. Pada siklus I siswa yang mencapai ketuntasan sebesar 40\% (14 siswa), sedangkan yang belum mencapai ketuntasan sebesar $60 \%$ (21 siswa). Hasil tersebut belum mencapai target ketuntasan yang ditentukan untuk aspek pengetahuan yaitu sebesar $60 \%$. Pada siklus II siswa yang mencapai ketuntasan aspek pengetahuan sebesar $71 \%$ (25 siswa), sedangkan yang belum tuntas sebesar $29 \%$ (10 siswa). hasil tersebut sudah mencapai target yang ditentukan.

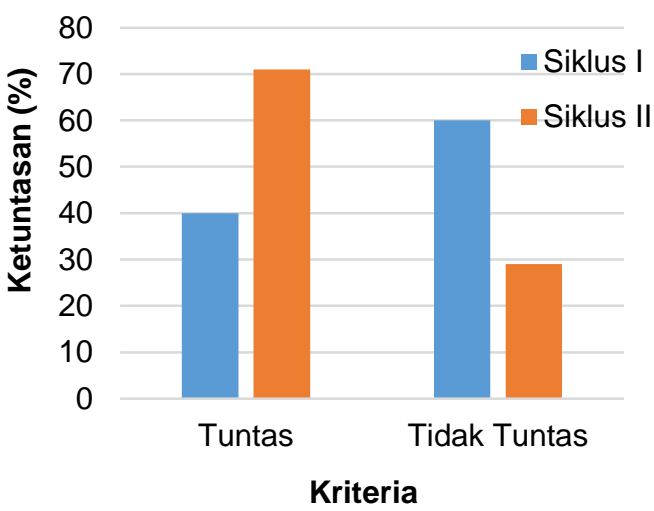

Gambar 7. Perbandingan Hasil Penilaian Aspek Pengetahuan Siklus I dan II

Pada siklus II, pembelajaran dan penilaian difokuskan pada indikator yang belum tuntas. Perbandingan persentase ketuntasan aspek pengetahuan siklus I dan II tiap indikator disajikan dalam Tabel 5.
Tabel 5. Perbandingan Persentase Ketercapaian Aspek Pengetahuan Siklus I dan II Tiap Indikator

\begin{tabular}{ccccc}
\hline & \multicolumn{2}{c}{ Siklus I } & \multicolumn{2}{c}{ Siklus II } \\
\cline { 2 - 5 } IK & $\begin{array}{c}\text { Keterca- } \\
\text { paian (\%) }\end{array}$ & $\begin{array}{c}\text { Kri- } \\
\text { teria }\end{array}$ & $\begin{array}{c}\text { Keterca- } \\
\text { paian (\%) }\end{array}$ & $\begin{array}{c}\text { Kri- } \\
\text { teria }\end{array}$ \\
\hline 1 & 70 & $\mathrm{~T}$ & - & \\
2 & 65 & $\mathrm{~T}$ & - & \\
3 & 47 & $\mathrm{BT}$ & 71 & $\mathrm{~T}$ \\
\hline${ }^{*} \mathrm{~T}=$ Tuntas, BT= Belum Tuntas & &
\end{tabular}

Berdasarkan hasil siklus I dan II, semua aspek telah mencapai target yang ditentukan sehingga pelaksanaan penelitian dihentikan pada siklus II. Dari hasil tersebut dapat diketahui bahwa penerapan model pembelajaran inkuiri terbimbing dapat meningkatkan sikap ilmiah dan prestasi belajar siswa. Seperti pada penelitian yang dilakukan oleh Kurniasari [11] bahwa penerapan model pembelajaran inkuiri terbimbing dapat meningkatkan prestasi belajar siswa pada materi kelarutan dan hasil kali kelarutan. Secara keseluruhan penerapan model pembelajaran inkuiri terbimbing dengan media diagram $\mathrm{V}$ pada materi hidrolisis garam yang diterapkan pada kelas XI MIPA 2 SMA Negeri 1 Banyudono dapat dikatakan berhasil.

\section{KESIMPULAN}

Penerapan model pembelajaran inkuiri terbimbing (Guided Inquiry) dengan media diagram $V$ dapat meningkatkan sikap ilmiah dan prestasi belajar siswa pada materi hidrolisis garam kelas XI MIPA 2 SMA Negeri 1 Banyudono tahun pelajaran 2017/2018. Hal ini ditunjukkan dari hasil ketercapaian sikap ilmiah siswa pada siklus I sebesar $82,86 \%$. Ketuntasan aspek pengetahuan siklus I sebesar $40 \%$ kemudian meningkat menjadi $71 \%$ pada siklus II, ketuntasan aspek sikap pada siklus 1 sebesar 91,43\%., dan ketuntasan aspek keterampilan pada siklus 1 sebesar $85,71 \%$.

\section{UCAPAN TERIMA KASIH}

Penulis mengucapkan terima kasih kepada semua pihak yang telah membantu dan mendukung terselesai- 
nya penelitian ini. Kepada Bapak Drs. Mulyadi Joko selaku kepala SMA Negeri 1 Banyudono dan Ibu Magdalena Adam selaku guru kimia kelas XI MIPA SMA Negeri 1 Banyudono yang telah memberikan ijin untuk melakukan penelitian dan menggunakan kelas XI MIPA 2 untuk penambilan data penelitian. Serta siswasiswi kelas XI MIPA SMA Negeri 1 Banyudono yang telah membantu dalam penelitian ini.

\section{DAFTAR RUJUKAN}

[1] Goldberg, D. E., 2003, Kimia Untuk Pemula, Erlangga, Jakarta.

[2] Anwar, H., 2009, Jurnal Pelangi IImu, 2(5), 103-114.

[3] Ristanto, R. H., Zubaidah, S., Amin, M., \& Rohman, F., 2017, International Journal of Research and Review, 4(5).

[4] Almuntasheri, S., Gillies, R. M., \& Wright, T., 2016, Science Education International, 27(1), 16-39.
[5] Dahar, R. W., 2011, Teori-teori Belajar dan Pembelajaran, Erlangga, Jakarta.

[6] Mulyasa, D., 2011, Pendidikan Bermutu dan Berdaya Saing, Remaja Rosdakarya, Bandung.

[7] Vlassi, M., Karaliota, A., 2013, Proceedings Social and Behavioral Sciences 98, 494-497.

[8] Dewi, N. L., Dantes, N., Sadia, I. W., 2013, PENDASI: Jurnal Pendidikan Indonesia, 3(1).

[9] Arikunto, S. 2012. Penelitian Tindakan Kelas, Bumi Aksara, Jakarta.

[10] Sugiyono, 2012, Metode Penelitian Kuantitatif, Kualitatif, dan R\&D, Alfabeta, Bandung.

[11] Kurniasari, A. W., Setyowati, W. A. E., \& Utomo, S. B., Jurnal Pendidikan Kimia, 2016, 5(4), 98-105. 